\title{
School Climate Indices as Predictors of Teacher Job Satisfaction and Performance in Oyo State, Nigeria
}

\author{
Ibikunle F. Akinnola, Afolakemi O. Oredein \\ Department of Educational Management, Faculty of Arts \& Education, Lead City University, Ibadan, Oyo State, Nigeria
}

Email address:

ibikunleakinnola@gmail.com (I. F. Akinnola),opefolake1@yahoo.com (A. O. Oredein)

\section{To cite this article:}

Ibikunle F. Akinnola, Afolakemi O. Oredein. School Climate Indices as Predictors of Teacher Job Satisfaction and Performance in Oyo State, Nigeria. Teacher Education and Curriculum Studies. Vol. 6, No. 2, 2021, pp. 51-60. doi: 10.11648/j.tecs.20210602.12

Received: July 27, 2020; Accepted: September 1, 2020; Published: May 14, 2021

\begin{abstract}
School climates indices as predictors of teacher job satisfaction and performance in Oyo State of Nigeria were investigated in this study. The school climate indices include; school laboratories, libraries, classrooms and instructional materials. This was a descriptive survey research which was questionnaire based. The population of the study was all public secondary school teachers in Oyo State, Nigeria. Multi-stage using cluster and simple random sampling techniques to select a total of one thousand and five hundred (1500) teachers (male and female) from the selected public secondary schools for the study. Three research questions and six hypotheses were postulated. Hypotheses were tested at $5 \%$ level of significance. The data collected for the study were analyzed using descriptive analysis, Multiple Regression analysis, MANOVA, Pearson Product Moment Correlation and t-test. Among others, the study revealed that the level of teachers' job satisfaction was lower than the performance with the overall weighted average of 2.380 and 2.702 respectively. Only $11.7 \%$ public secondary schools in Oyo State, Nigeria were able to meet up with the UNESCO recommended student-teacher ratio. Also, there exist a significant combined influence of school climate indices on the teachers' job satisfaction and performance $(\mathrm{F}=11.919 ; \mathrm{P}<0.05)$. As a result of the findings, it was recommended that government should allocate sufficient fund in the budget for the provision of instructional materials, modern libraries, and well equipped laboratories to create a good school climate in public secondary schools. Also, the suggested UNESCO student-teacher ratio should be adhering to.
\end{abstract}

Keywords: School Climate, Teachers' Job Satisfaction, Teachers' Job Performance, Oyo State, Nigeria

\section{Introduction}

Teachers are indispensable for the effective running of the school or education system. Teachers are the implementers who impact into the learners, values and ideas which are considered vital to the socio-cultural, political and economic development through the teaching of basic relevant concepts. Also, teachers play a central role in constructing and molding the personality of learners. The importance of teachers in the process of teachinglearning activities cannot be overemphasized.

From the foregoing, it is evidently clear that teachers occupy a very sensitive position in the achievement of educational goals as well as the national development of any country. A good and visionary teacher plays a prominent role in determining the future of any learner. It is equally imperious that the importance of a teacher as an architect of the future generation demands that the individual has to be a cognoscente.
Gone are those days when people are proud to be called teachers simply because of the joy that are being derived from teaching profession. Teachers are all out to teach with all might and strength giving learners about $75 \%$ information needed while learners will read for the remaining $25 \%$. But down the years, the story changed and people started to lose interest in teaching, no more societal recognition and people who have no other course to study are now been admitted to study education. Hence, the satisfaction that supposed to be derived from teaching are now been affected. And when someone is not satisfied in whatever one is doing, most likely the performance can be affected as well. Nowadays, schools make it compulsory for learners to attend lesson after the school hours. In fact, some learners will still have private home lesson after the one organized in the schools. In addition, teachers will pile up home-work for learners to do from home what should have probably been done in the class. 
A teacher with a high level of job satisfaction and performance is more likely to produce happy, stable and highly inventive learners, who would be proactive and productive in the course of nation building. While a teacher with a low level of job satisfaction and performance might end up producing a lazy, muddled and uncreative learners who will later become liability and problematic to the nation. Job satisfaction is how happy and content an individual is with his or her job. It is the pleasure an individual derive from doing his job [2]. It is the pleasure an individual derive from doing his job. Job satisfaction is an affective or emotional response towards facets of one's job [3]. It can be viewed as the workers' feelings and state of mind about what he does in relation to his job and a sense of happiness and fulfillment a worker has when he discovers that his expectations of the job are being met. It can also be perceived as the positive emotional state one felt after self-evaluation in line with one's job and work experience [4].

The feat of job satisfaction is not constrained to certain professions; rather, it cuts across all works of life including the teaching profession. Teacher job satisfaction is made up of varied values which a teacher either consciously or unconsciously desire to obtain or derive from teaching job. It is a subjective feeling a teacher has on the basis of personal judgment about the teaching profession. Such personal judgments are usually in agreement with the teacher's objectives and the core values he/she attached to teaching profession [5]. There are no doubts that teachers join teaching profession with the main aim of satisfying their varied needs. When it is now discovered that the expectations are realized, they tend to exhibit a sense of fulfillment and job satisfaction; and if otherwise, they feel uncomfortable, insecure and dissatisfied with the job. The level of teacher job satisfaction differs from one teacher to another with respect to gender, age, experience, marital status and qualification. Personal attributes and traits, such as, likes and dislikes, individual cultural backgrounds, organizational settings, environmental factors, rewards and remunerations as well as recognition could form the basis of explaining different levels of satisfaction among teachers [6].

Job performance is the overall behaviors in relation to the job. It assesses whether a person performs a job well or otherwise. Job performance is the implementation of an action or one's ability [7]. Good job performance is related to achieving the quality, quantity, dependability and creativity. The notion of job performance can be viewed from different perspective. Firstly, the determination of what employees are expected to do as indicated by the employers viz-a-viz what the employees are actually doing. Secondly, the determination of employees' actual workload alongside with whether it is too heavy or light. Thirdly, assuming that an employee has a clear outline of what the job description is, there are certain variables which might enhance or hinder employees' efforts as well as willingness or desire to perform effectively and efficiently. Teachers' job performance is dynamic, varied and all encompassing. A teacher is required to take up expanded roles and responsibilities including; curriculum developer, a mentor, facilitator, motivator, team leader, researcher, decision maker, innovator and a mobilizer
[8]. Duties of teachers are to be discharged more within the school system and be extended to the society at large.

The school climate is a broad term and concept which embraces the classrooms, libraries, workshops, laboratories, instructional materials and the school environment in general. It includes the social atmosphere of a setting, or learning environment in which students have different experiences. The school climate is the heart and the soul of a school [9]. The effectiveness of school and its success in achieving its set goals are closely attached to the school climate. This is because teachers' attitudes are directly related to the school facilities available. A favourable school climate provides the structure within which teachers, students, administrators and parents can function cooperatively and constructively. Teachers in a positive school environment where educational facilities are adequately provided mostly likely exhibits positive behaviour which is more lenient, influential, supportive, warm and concerned towards learners. Learners will likely be existed and demonstrated self-direction and freedom towards learning. Learners with comfortable school environment are better motivated to learn and they exhibit behaviour which is positive towards learning [10]. It is equally evident that learning is more effective when sensory experiences are stimulated.

Having a close look at the physical environment of many public schools in Oyo State, and even Nigeria at large presents a sorry sight with awful dilapidated buildings, dingy classrooms devoid of seats and writing tables, and lack of or non-functional instructional materials, bad conveniences for both the staff and learners, non-functional library, non-well equipped science laboratories for practical, among others. Oyo State is one of the six southwest states in Nigeria. Teachers in Oyo State, sometimes go to classes to teach learners virtually without instructional materials, thereby, teaching in abstract, as the concepts taught are not presented or brought into the realities of the learners. The lessons are dry, uninteresting and boring to learners; even the entire school system seems to be a waste of time and not worthwhile to the learners. In the light of this, only few serious learners struggle and strive to memorize or cram concepts taught just to pass examinations, while a large proportion of the learners perform poorly academically especially in external examinations [11].

The shortage of classrooms in many schools especially in public schools where the best supposed to be found being the government owned schools is so acute that more than sixty learners occupy classrooms that are meant for about thirty students according to the UNESCO recommendation. In most public schools, based on observation as teachers and experience gathered during teaching practice supervision, classroom furniture and other classroom facilities are grossly inadequate. Where classes are overcrowded, neither the teacher nor the learner can move freely as expected in secondary classrooms and which can lead to survival of the fittest. This is why many teachers failed to give assignments to such large number of learners regularly thinking of the stress to mark which in turn has negatively affected the outputs of educational school system. In such overcrowded classrooms, the experience amidst the learners will be 
'survival of the fittest' while the low learners might not be taken care off. Even in some public schools classes are be taken under the trees because of the dilapidated classrooms where classroom roofs have removed may be by the wind and not replaced. Students have to carry tables and chairs from respective homes to school and names written on the furniture. And students without furniture will have to manage with friends otherwise stand by the window to receive classes.

Library facilities in most Nigerian schools may be described as unsatisfactory. Library without current books and not even conducive for reading comparing with what a 21 st century educational library should look like. Most of the books in the library are not current but rather outdated and are not in conformity with the new curriculum and subjects taught in school. This situation depicts that students are discouraged from cultivating reading culture which is highly indispensable to writing skills, research and national development.

Based on this study, the school climate factors are school laboratory, library, instructional materials, student-teacher ratio and classroom condition. The purpose of this study is to investigate the influence of the school climate indices on teachers' job satisfaction and performance in public secondary school in Oyo State, Nigeria. Also, to identify the state of public school climate, and level of teachers' job satisfaction and performance in public secondary schools in Oyo State.

The theoretical framework is Herzberg Two Theory developed by a psychologist named Frederick Herberg which states that there are certain factors in the workplace that can cause both job satisfaction and dissatisfaction.

\section{Statement of the Problem}

Teachers play a pivot role in achieving goals and objectives of molding learners to excel in academics. Incessant teachers' strike is increasing which could have been due to so many reasons, like; the deplorable condition of public secondary schools regarding the school climate, poor job performance and satisfaction. That has given so much concern to all education stakeholders in the state. This in turn could affect learners' academic performance in both internal and external examinations. A poor school environment does not only affect the output of the school system but as well as the teachers who are the facilitators of teaching-leaching activities. Situations where there is no job security, irregularity in salary payment, poor working condition, lack of promotion as at when due, and non-recognition among others could have been sources of poor job satisfaction and performance of teachers in secondary schools. If this aforementioned situation is not effectively addressed then learners will continue to perform dismally in examination and educational system will continue to decline. Also, there will be increase in teachers' turnover and the trend may undercut quest for the schools to achieve the stated goals and objectives. Researchers have worked on the relationship between supportive work environment and teachers' job satisfaction [12]; leadership style and teachers' job satisfaction [13]; and lecturers' job commitment and performance [14]. However, relatively little empirical research has been conducted looking at both teachers' job satisfaction and performance at the same time. To this end, this study seeks to examine school climate indices as predictors of teachers' job satisfaction and performance in Oyo State, Nigeria.

Research Questions

1. What is the state of school climate in the public secondary schools?

2. What is the level of teachers' job satisfaction in the public secondary schools?

3. What is the level of teachers' job performance in the public secondary schools?

Hypotheses

The following null hypotheses were generated for the study.

Ho1: There will be no significant combined influence of school climate indices (laboratories, libraries, classrooms and instructional materials) on teachers' job satisfaction and performance in Oyo state.

Ho2: There will be no significant combined influence of school climate indices (laboratories, libraries, classrooms and instructional materials) on teachers' job satisfaction in Oyo state.

Ho3: There will be no significant relative influence of school climates indices (laboratories, libraries, classroom and instructional materials) on teachers' job satisfaction in Oyo state

Ho4: There will be no significant combined influence of school climate indices (laboratories, libraries, classroom and instructional materials) on teachers' job performance in Oyo state

Ho5: There will be no significant relative influence of school climate indices (laboratories, libraries, classroom and instructional materials) on teachers' job performance in Oyo state.

Ho6: There will be no significant gender difference in teachers' job satisfaction and performance in Oyo state.

\section{Methodology}

The research design is descriptive design of survey type. Study population comprises all public secondary school teachers in Oyo state. Sampling techniques are multi-stage, clustered and simple random sampling techniques. At present, there are a total of 604 public secondary schools in Oyo state. These schools are clustered over the 3 senatorial districts with their local government areas. First stage, 5 local government areas from each senatorial district were randomly selected making 15 local governments. Second stage, 10 schools were further randomly selected from each local government areas making 150 schools. Third stage, from the 150 schools selected, 10 teachers were randomly selected from each school making a total sample of 1500 teachers. 
The research instrument for this study is divided into four sections, namely; A, B, C and D. Section A is designed to elicit information on personal data of the respondents. Section $\mathrm{B}$ was designed to measure the school climate. Section C and D are adapted structured items to elicit information on teachers' job satisfaction and job performance respectively (Goodman \& Svyantek, 1999) using four Likert Scale (Very Often $=4$, Often $=3$, Not often $=2$, and Never $=1$ ).

A pilot study was carried out to validate the instrument and the reliability of the instrument was tested using the testretest method to establish the stability principle and co- efficient is 0.89 . The data was subjected to statistical test and analysis, using descriptive statistics like percentage, and mean for the research questions. MANOVA for hypothesis one while Regression analysis (ANOVA) was used for hypotheses two to five and t-test was used for hypothesis six all at $5 \%$ level of significance.

\section{Result}

Research Question One: What is the level of teachers' job satisfaction?

Table 1. Teacher Job Satisfaction.

\begin{tabular}{|c|c|c|c|c|c|c|}
\hline $\mathbf{S} / \mathbf{N}$ & Items & Very Often & Often & Not Often & Never & Weighted Average \\
\hline 1 & I enjoy teaching & $539(35.9 \%)$ & $362(24.1 \%)$ & $358(23.9 \%)$ & $241(16.1 \%)$ & 2.7993 \\
\hline 2 & Sometimes I get bored with teaching & $240(16 \%)$ & $300(20 \%)$ & $601(40.1 \%)$ & $359(23.9 \%)$ & 2.2807 \\
\hline 3 & My job can secure a good future for me & $421(28.1 \%)$ & $418(27.9 \%)$ & $303(20.2 \%)$ & $358(23.9 \%)$ & 2.6013 \\
\hline 4 & I sometimes feel that I am wasting my time doing this job & $183(12.2 \%)$ & $299(19.9 \%)$ & $689(45.9 \%)$ & $329(21.9 \%)$ & 2.2240 \\
\hline 5 & In my society, teaching is a valued and respectable profession & $838(55.9 \%)$ & $304(20.3 \%)$ & $358(23.9 \%)$ & $0(0.0 \%)$ & 3.320 \\
\hline 6 & I am promoted as at when due & $181(12.1 \%)$ & $300(20 \%)$ & $421(28.1 \%)$ & $598(39.9 \%)$ & 2.0427 \\
\hline 7 & There is no opportunity to learn new skills in teaching & $242(16.1 \%)$ & $302(20.1 \%)$ & $418(27.9 \%)$ & $538(35.9 \%)$ & 2.1653 \\
\hline 8 & Advanced and additional training is limited in my job & $359(23.9 \%)$ & $423(28.2 \%)$ & $359(23.9 \%)$ & $359(23.9 \%)$ & 2.5213 \\
\hline 9 & $\begin{array}{l}\text { My job provides me the opportunity of utilizing properly my } \\
\text { talents and potentials }\end{array}$ & $481(32.1 \%)$ & $422(28.1 \%)$ & $358(23.9 \%)$ & $239(15.9 \%)$ & 2.7633 \\
\hline 10 & $\begin{array}{l}\text { Promotion of teachers is based on arbitrary choices than } \\
\text { capabilities and merit }\end{array}$ & $661(44.1 \%)$ & $418(27.9 \%)$ & $242(16.1 \%)$ & $179(11.9 \%)$ & 3.0407 \\
\hline 11 & I am satisfied with my income. & $2(0.1 \%)$ & $1(0.1 \%)$ & $359(23.9 \%)$ & $1138(75.9 \%)$ & 1.2447 \\
\hline 12 & Retirement benefits are timely paid to teachers. & $2(0.1 \%)$ & $238(15.9 \%)$ & $422(28.1 \%)$ & $838(55.9 \%)$ & 1.6027 \\
\hline 13 & My income can adequate take care of my expenses & $1(0.1 \%)$ & $2(0.1 \%)$ & $122(8.1 \%)$ & $1375(91.7 \%)$ & 1.0860 \\
\hline 14 & The payment for extra work is adequate. & $3(0.2 \%)$ & $298(19.9 \%)$ & $601(40.1 \%)$ & $598(39.9 \%)$ & 1.8040 \\
\hline 15 & $\begin{array}{l}\text { In teaching profession, teachers are given rewards for their hard } \\
\text { work. }\end{array}$ & $62(4.1 \%)$ & $420(28 \%)$ & $658(43.9 \%)$ & $360(24 \%)$ & 2.1227 \\
\hline 16 & The work environment in my school is uninviting. & $718(47.9 \%)$ & $541(36.1 \%)$ & $61(4.1)$ & $180(12 \%)$ & 3.1980 \\
\hline 17 & $\begin{array}{l}\text { Instructional facilities required for teaching and learning are } \\
\text { available in my school. }\end{array}$ & $361(24.1 \%)$ & $360(24 \%)$ & $421(28.1 \%)$ & $358(23.9 \%)$ & 2.4827 \\
\hline 18 & My school provides a comfortable working environment. & $238(15.9 \%)$ & $542(36.1 \%)$ & $420(28 \%)$ & $300(20 \%)$ & 2.4787 \\
\hline 19 & The work environment in my school enhances teaching and learning. & $181(12.1 \%)$ & $360(24 \%)$ & $541(36.1 \%)$ & $418(27.9 \%)$ & 2.2027 \\
\hline 20 & Physical surroundings in my school are unpleasant. & $301(20.1 \%)$ & $598(39.9 \%)$ & $422(28.1 \%)$ & $179(11.9 \%)$ & 2.6807 \\
\hline 21 & My supervisor is approachable. & $300(20 \%)$ & $420(28 \%)$ & $360(24 \%)$ & $420(28 \%)$ & 2.4000 \\
\hline 22 & My supervisor never listens to suggestion. & $358(23.9 \%)$ & $182(12.1 \%)$ & $603(40.2 \%)$ & $357(23.8 \%)$ & 2.3607 \\
\hline 23 & My supervisor is kind and supportive. & $363(24.2 \%)$ & $597(39.8 \%)$ & $302(20.1 \%)$ & $238(15.9 \%)$ & 2.7233 \\
\hline 24 & My supervisor has a bossy nature. & $417(27.8 \%)$ & $543(36.2 \%)$ & $478(31.9 \%)$ & $62(4.1 \%)$ & 2.8767 \\
\hline \multirow[t]{2}{*}{25} & My supervisor always makes fair and impartial decision. & $243(16.2 \%)$ & $477(31.8 \%)$ & $542(36.1 \%)$ & $238(15.9 \%)$ & 2.4833 \\
\hline & OVERALL WEIGHTED AVERAGE & & & & & 2.3802 \\
\hline
\end{tabular}

Source: Field Survey (2019)

The result from table 1 showed an overall weighted average of 2.380 which is below the expected weighted average of 2.50. This implies that the teachers' job satisfaction in is low. Response to question one on the table revealed that about $35.9 \%$ of the respondent very often enjoy teaching, $24.1 \%$ often enjoy teaching, while $23.9 \%$ and $16.1 \%$ not often and never enjoy teaching. $16 \%$ of the teachers affirmed that they very often get bored with teaching, $20 \%$ often get bored, $40.1 \%$ not often get bored, and $23.9 \%$ never get bored. To the question of whether teaching job can secure good future, about $28.1 \%$ of the teachers responded very often, $27.9 \%$ responded often, while $20.2 \%$ and $23.9 \%$ responded not often and never respectively. $12.2 \%$ responded very often, to the questions $i$ sometime feel that $\mathrm{i}$ am waiting my time doing this job, while about $19.9 \%, 45.9 \%$ and $21.9 \%$ of the teachers responded often, not often and never. Responses showed that only $0.1 \%$ of the teachers acclaimed that very often and often their income can adequately take care of their expenses, while $8.1 \%$ and $91.7 \%$ affirmed that income is not often and never adequate to take care of their expenses. Overview of the level of teacher's satisfaction vis-à-vis the nature of their job, working condition, remuneration and supervision reflect high possibilities that teachers sampled in the study have somewhat low level of job satisfaction.

Research Question Two: What is the level of teachers' job performance? 
Table 2. Teacher's Job performance in Oyo State.

\begin{tabular}{|c|c|c|c|c|c|c|}
\hline $\mathbf{S} / \mathbf{N}$ & Items & Very Often & Often & Not Often & Never & Weighted Average \\
\hline 1 & Work towards achieving teaching objectives & $898(59.9 \%)$ & $362(24.1 \%)$ & $178(11.9 \%)$ & $62(4.1 \%)$ & 3.8287 \\
\hline 2 & As a teacher, I meet the criteria for job performance & $1254(83.6 \%)$ & $238(15.9 \%)$ & $5(0.3 \%)$ & $3(0.2 \%)$ & 3.3973 \\
\hline 3 & Demonstrate expertise in teaching related tasks & $418(27.9 \%)$ & $897(59.8 \%)$ & $183(12.2 \%)$ & $2(0.1 \%)$ & 3.1540 \\
\hline 4 & I fulfill all the requirements of teaching job & $599(139.9 \%)$ & $719(47.9 \%)$ & $181(12.1 \%)$ & $1(0.1 \%)$ & 3.2773 \\
\hline 5 & I could manage more responsibility than typically assigned & $363(24.2 \%)$ & $542(36.1 \%)$ & $417(27.8 \%)$ & $178(11.9 \%)$ & 2.7267 \\
\hline 6 & I am competent in all areas of teaching job & $958(63.9 \%)$ & $362(24.1 \%)$ & $179(11.9 \%)$ & $1(0.1 \%)$ & 3.5180 \\
\hline 7 & I handle tasks with proficiency and meet deadlines & $661(44.1 \%)$ & $299(19.9 \%)$ & $242(16.1 \%)$ & $298(19.9 \%)$ & 2.8820 \\
\hline 8 & $\begin{array}{l}\text { I perform well in the overall teaching job by carrying out } \\
\text { tasks as expected }\end{array}$ & $1078(71.9 \%)$ & $420(28.0 \%)$ & $1(0.1 \%)$ & $1(0.1 \%)$ & 3.7167 \\
\hline 9 & $\begin{array}{l}\text { I plan and organize my lessons to achieve teaching objectives } \\
\text { conscientiousness }\end{array}$ & $1259(83.9 \%)$ & $238(15.9 \%)$ & $5(0.1 \%)$ & $1(0.1 \%)$ & 3.8367 \\
\hline 10 & I am punctual in arriving at school & $358(23.9 \%)$ & $542(36.1 \%)$ & $599(39.9 \%)$ & $1(0.1 \%)$ & 2.8380 \\
\hline 11 & I am punctual in attending classes & $360(24 \%)$ & $900(60.0 \%)$ & $180(12.0 \%)$ & $60(4.0 \%)$ & 3.0400 \\
\hline 12 & I take undeserved work holidays & $3(0.2 \%)$ & $3(0.2 \%)$ & $477(31.8 \%)$ & $1017(67.8 \%)$ & 1.3280 \\
\hline 13 & I closes towards the end of the day & $2(0.1 \%)$ & $1138(75.9 \%)$ & $239(15.9 \%)$ & $12.1(8.1 \%)$ & 2.6807 \\
\hline 14 & Gives advance notice if unable to come to school & $181(12.1 \%)$ & $1018(67.9 \%)$ & $179(11.9 \%)$ & $122(8.1 \%)$ & 2.8387 \\
\hline 15 & Engage in personal business during the school hour & $0(0.0 \%)$ & $(0.1 \%)$ & $361(24.1 \%)$ & $1138(75.9 \%)$ & 1.2420 \\
\hline 16 & Take unnecessary time off work & $1(0.1 \%)$ & $2(0.1 \%)$ & $299(19.9 \%)$ & $1198(79.9 \%)$ & 1.2040 \\
\hline 17 & Get involve in idle conversation during the school hour & $0(0.0 \%)$ & $0(0.0 \%)$ & $180(12 \%)$ & $1320(88 \%)$ & 1.1200 \\
\hline 18 & Spends a great deal of time in personal phone conversation & $1(0.1 \%)$ & $123(8.2 \%)$ & $717(47.8 \%)$ & $659(43.9 \%)$ & 1.6440 \\
\hline 19 & Helps other teachers with their work when they are absent & $360(24 \%)$ & $720(48 \%)$ & $181(12.1 \%)$ & $239(15.9 \%)$ & 2.8007 \\
\hline 20 & Volunteers to do things not formally required by teaching job & $182(12.1 \%)$ & $359(23.9 \%)$ & $362(24.1 \%)$ & $597(39.8 \%)$ & 2.0840 \\
\hline 21 & Takes initiatives to orient new teachers & $899(59.9 \%)$ & $422(28.1 \%)$ & $60(4.0 \%)$ & $119(7.9 \%)$ & 3.4007 \\
\hline 22 & Assists teachers with high workloads and periods & $358(23.9 \%)$ & $360(24 \%)$ & $422(28.1 \%)$ & $360(24 \%)$ & 2.4773 \\
\hline 23 & Get involved in extracurricular activities & $0(0.0 \%)$ & $840(56 \%)$ & $480(32 \%)$ & $180(12 \%)$ & 2.4400 \\
\hline 24 & $\begin{array}{l}\text { Makes innovative suggestions to improve the overall quality } \\
\text { of teaching }\end{array}$ & $478(31.9 \%)$ & $601(40.1 \%)$ & $359(23.9 \%)$ & $62(4.1 \%)$ & 2.9967 \\
\hline \multirow[t]{2}{*}{25} & $\begin{array}{l}\text { Willingly attends programs that will contribute to the } \\
\text { improvement of teaching, learning process. }\end{array}$ & $478(31.9 \%)$ & $660(44 \%)$ & $360(24 \%)$ & $2(0.1 \%)$ & 3.0760 \\
\hline & OVERALL WEIGHTED AVERAGE & & & & & 2.7019 \\
\hline
\end{tabular}

Source: Field Survey (2019)

As reported in table 2, 59.9\% of the sampled teachers acclaimed that they very often work towards achieving teaching objectives, as against $24.1 \%$ responded often, $11.9 \%$ responded not often and $4.1 \%$ responded never. $83.6 \%$ of the teacher submitted that they very often meet the criteria for job performance, as against $15.9 \%, 0.3 \%$ and $0.2 \%$ that often, not often and never meet criteria for job performance. About $27.9 \%$ of the teachers very often demonstrate expertise in teaching related tasks, while $59.8 \% 12.2 \%, 0.1 \%$ often, not often and never demonstrated expertise in teaching related task. 39.9\% very often fulfill all the requirements for teaching job, responses for often stood at $47.9 \%$, responses for not often stood at $12.1 \%$ while $0.1 \%$ acclaimed never. Responses to punctuality at school at $23.9 \%$ for very often, $36.1 \%$ for often, $39.9 \%$ for not often and $0.1 \%$ for never. Response for punctuality in classes stood at $24 \%$ for very often, $60 \%$ for often, $12 \%$ for not often, and $4 \%$ for never. $31.9 \%$ of the sampled teachers claimed to very often make innovative suggestion to improve the overall quality of teaching, $40.1 \%$ often do so, $23.9 \%$ not often do so while $4.1 \%$ never do so. $31.9 \%$ of the respondents very often willingly attend programs that will contribute to the improvement of teaching and learning process, $44 \%$ often willingly do so,

$24 \%$ not often do so while $0.1 \%$ of the respondents never do so. The overall weighted average from table 2 above, reflected that on the average teachers sampled in the study possess attributes of high level of job performance of an overall weighted average of 2.70 against the expected of 2.50 .

Research Question Three: What is the state of school climate?

Table 3. School Climate.

\begin{tabular}{|c|c|c|c|c|c|c|c|}
\hline \multicolumn{8}{|l|}{ Educational Facilities } \\
\hline Items & Available & Not Available & Adequate & Inadequate & Functional & Not Functional & Weighted Average \\
\hline Instructional Materials & $238(15.9 \%)$ & $452(30.1 \%)$ & $183(12.2 \%)$ & $267(17.8 \%)$ & $119(7.9 \%)$ & $241(16.1 \%)$ & 3.036 \\
\hline Modern Library & $106(7.1 \%)$ & $617(41.1 \%)$ & $121(8.1 \%)$ & $236(15.7 \%)$ & $122(8.1 \%)$ & $298(19.9 \%)$ & 2.433 \\
\hline Availability of classrooms & $438(29.2 \%)$ & - & $183(12.2 \%)$ & $467(31.1 \%)$ & $160(10.6 \%)$ & $254(16.9 \%)$ & 2. 106 \\
\hline \multicolumn{8}{|l|}{ Class Room Condition } \\
\hline Item & $20-30$ & $31-40$ & $41-50$ & $51-60$ & 61 and above & & \\
\hline
\end{tabular}

Source: Field Survey, (2019) 
Table 3 reported that instructional materials was acclaimed as been available $15.9 \%(238)$, not available $30.1 \%(452)$, adequate $12.2 \%(183)$, inadequate $17.8 \%(267)$, functional $7.9 \%(119)$, and not functional 16.1\%(241). Modern libraries was acclaimed as available 7.1\%(106), not available $41.1 \%(617)$, adequate $8.1 \%(121)$, inadequate $15.7 \%(236)$, functional $8.1 \%(122)$, and not functional $19.9 \%(298)$. In the same vein well equipped laboratory was acclaimed as available $7.9 \%$ (118), not available $33.1 \%(496)$, adequate $6.3 \%(95)$, inadequate $26.8 \%(402)$, functional $6.2 \%(93)$ and not functional $19.7 \%(296)$. The result revealed that classroom was acclaimed been $438(29.2 \%)$ available, 467
(31.1\%) inadequate, and 254 (16.9\%) non- functional, the highest student-teacher ratio was 41-50 (26.1\%) which against the UNESCO recommendation of 30-35. There were more inadequate classrooms $467(31.1 \%)$ for teachinglearning activities. With the congested class room condition and educational facilities in secondary schools in Oyo state that are largely inadequate, not functional and/or not available, there is undoubted evidence that school climate in Oyo state is far from being satisfactory.

Hypothesis One: There will be no significant combined influence of school climate indices on teacher's job satisfaction and performance in Oyo State.

Table 4. Model Summary ${ }^{b}$.

\begin{tabular}{llllll}
\hline Model & R & R Square & Adjusted R Square & Std. Error of the Estimate & Durbin-Watson \\
\hline 2 & $.678 \mathrm{a}$ & .658 & .667 & 3.31209 & 1.543 \\
\hline
\end{tabular}

a. Predictors: (Constant), School Climate Indices

b. Dependent Variables: Job Satisfaction and Job Performance

Table 5. MANOVA

\begin{tabular}{lllll}
\hline & Sum of & & Mean & \\
\hline Model & Squares & Df & Square & F \\
\hline 2 & Regression 676.284 & 2 & 338.142 & 11.919 \\
& Residual & 42469.89 & 1497 & 28.370 \\
& Total & 43146.174 & 1498 & $.002 \mathrm{a}$ \\
\end{tabular}

a. Predictors: (Constant): School Climate Indices

b. Dependent Variable: Job Satisfaction and Job Performance

Tables 4 and 5 revealed that the joint effect of the independent variables that is, the school climate indices (instructional materials, library, laboratory and classroom) will significantly influence teachers' job satisfaction and performance in Oyo State with $\mathrm{P}<0.05$. Hence, the null hypothesis is rejected. $\mathrm{R}^{2}$ which is the co-efficient of determination showed that the independent variables that is, the school climate indices account for a high proportion of about $66 \%$ of teachers' job satisfaction and performance.
Also, the standard error of estimated means is 3.312. This implies that the factors are relevant towards the determination of the dependent measure. Results do accord with Lodess \& Jowore (2015) that school climate have proven to be the primary variable affecting teachers' job satisfaction.

Hypothesis Two: There will be no significant combined influence of school climate indices on teacher's job satisfaction in Oyo State.

Table 6. Model Summary.

\begin{tabular}{llllll}
\hline Model & R & R Square & Adjusted Square & R Std. the Estimate & Error of Durbin-Watson \\
\hline 1 & $.688 \mathrm{a}$ & .648 & .637 & 5.22209 & 1.533 \\
\hline
\end{tabular}

a. Predictors: (Constant): School Climate Indices

b. Dependent Variable: Job Satisfaction

Table 7. ANOVA

\begin{tabular}{lllllll}
\hline Model & & Sum of Squares & Df & Mean Square & F & Sig. \\
\hline 1 & Regression & 321.763 & 1 & 321.763 & 11.799 & $.001 \mathrm{a}$ \\
& Residual & 40850.837 & 1498 & 27.270 & & \\
& Total & 41172.600 & 1499 & & & \\
\hline
\end{tabular}

a. Predictors: (Constant): School Climate Indices

b. Dependent Variable: Job Satisfaction

Result presented in tables 6 and 7 above showed that combined school climates indices has significant positive impact on teachers' job satisfaction in Oyo state given the reported coefficient estimate of 0.147 and probability value $\mathrm{p}=.001<0.05$. Hence, result showed that school climate indices including availability and adequacy of instructional materials, libraries, laboratory and classroom conduciveness jointly influence teacher's job satisfaction positively and significantly. In clear terms, result established evidence for the rejection of the null hypothesis that there will be no 
significant combined influence of selected school climate indices on teacher's job satisfaction in Oyo State. R2 which is the co-efficient of determination showed that the independent variables that is, the school climate indices account for a high proportion of about $64 \%$ of teachers' job satisfaction. Also, the standard error of estimated means is 5.22. This implies that the factors are relevant towards the determination of the dependent measure. Results do accord with Lodess \& Jowore (2015) that school climate have proven to be the primary variable affecting teachers' job satisfaction.

Hypothesis Four: There will be no significant relative influence of school climate indices on teacher's job satisfaction in Oyo State.

Table 8. Coefficients ${ }^{\mathrm{a}}$.

\begin{tabular}{llllll}
\hline \multirow{2}{*}{ Model } & & \multicolumn{2}{c}{ Unstandardized Coefficients } & \multicolumn{2}{c}{ Standardized Coefficients } \\
\cline { 3 - 6 } & & B & Std. Error & Beta & t \\
\hline 1 & (Constant) & 56.134 & .546 & 0.02 .749 & .000 \\
& Instructional Materials & 0.427 & 0.132 & 0.085 & 3.243 \\
& Modern Libraries & 0.423 & 0.144 & 0.076 & 2.925 \\
& Well Equipped Laboratory & 0.463 & 0.157 & 0.078 & 2.946 \\
& Conducive Classroom & 0.417 & 0.153 & 0.071 & 0.003 \\
\end{tabular}

a. Dependent Variable: Job Satisfaction

Result presented in the table 8 above showed that all school climate indices have significant positive influence on job satisfaction of teachers in Oyo state. Specifically coefficient estimates reported stood at $0.427(\mathrm{p}=0.001<$ $0.05)$ for instructional materials, $0.423(\mathrm{p}=0.003<0.05)$ for modern libraries, $0.463(\mathrm{p}=0.003<0.05)$ for equipped laboratory, and $0.417(\mathrm{p}=0.007<0.05)$ for conducive classroom. Results showed that there is enough evidence to reject the null hypothesis that there will be no significant relative influence of selected school climate indices on teacher's job satisfaction in Oyo State.

Hypothesis Five: There will be no significant combined influence of selected school climate indices on teacher's job performance in Oyo State.

Table 9. Model Summary ${ }^{b}$.

\begin{tabular}{|c|c|c|c|c|c|}
\hline Model & $\mathbf{R}$ & R Square & Adjusted R Square & Std. Error of the Estimate & Durbin-Watson \\
\hline 1 & $.614 a$ & .620 & .600 & 4.35751 & 1.381 \\
\hline
\end{tabular}

a. Predictors: (Constant): School Climate Indices

b. Dependent Variable: Job Performance

Table 10. ANOVA ${ }^{b}$.

\begin{tabular}{llllll}
\hline Model & & Sum of Squares & Df & Mean Square & F \\
\hline 1 & Regression & 5.777 & 1 & 5.777 & 11.304 \\
& Residual & 28443.823 & 1498 & 18.988 & $.001 \mathrm{a}$ \\
& Total & 28449.600 & 1499 & & \\
\hline
\end{tabular}

a. Predictors: (Constant): School Climate Indices

b. Dependent Variable: Job Performance

Result presented in tables 9 and 10 above showed that combined school climates indices has significant positive impact job performance of teachers in Oyo state $(\mathrm{F}=11.304$; $\mathrm{P}<0.05)$. Result showed that school climate indices including availability and adequacy of instructional materials, libraries, laboratory and classroom conduciveness jointly influence teacher's job performance positively and significantly. Hence there is enough evidence to reject the null hypothesis. R2 which is the co-efficient of determination showed that the independent variables that is, the school climate indices account for a high proportion of about $60 \%$ of teachers' job performance. Also, the standard error of estimated means is 4.357. This implies that the factors are relevant towards the determination of the dependent measure. This finding is in consistent with Emu \& Nwannunu [2] that school climate have constituted the best index of teachers' job performance.

Hypothesis Five: There will be no significant relative influence of school climate indices on teacher's job performance in Oyo State.

Table 11. Coefficients ${ }^{a}$.

\begin{tabular}{|c|c|c|c|c|c|c|}
\hline \multirow{2}{*}{\multicolumn{2}{|c|}{ Model }} & \multicolumn{2}{|c|}{ Unstandardized Coefficients } & \multicolumn{3}{|c|}{ Standardized Coefficients } \\
\hline & & B & Std. Error & Beta & $\mathbf{t}$ & Sig. \\
\hline \multirow[t]{5}{*}{1} & (Constant) & 67.243 & 0.459 & & 146.560 & .000 \\
\hline & Instructional Materials & 0.272 & 0.111 & 0.012 & 2.450 & 0.013 \\
\hline & Modern Libraries & 0.260 & 0.121 & 0.004 & 2.152 & 0.019 \\
\hline & Well Equipped Laboratory & 0.344 & 0.132 & 0.070 & 2.610 & 0.009 \\
\hline & Conducive Classroom & 0.248 & 0.129 & 0.051 & -1.927 & 0.044 \\
\hline
\end{tabular}

a. Dependent Variable: Job Performance 
Result presented in the table 11 above showed that all school climate indices have significant positive influence on job performance of teachers in Oyo state. Specifically coefficient estimates reported stood at $0.272(\mathrm{p}=0.013<$ $0.05)$ for instructional materials, $0.260(\mathrm{p}=0.019<0.05)$ for modern libraries, $0.344(\mathrm{p}=0.009<0.05)$ for equipped laboratory, and $0.248(\mathrm{p}=0.044<0.05)$ for conducive classroom. Well-equipped laboratory has more effect $(p=0.009)$, followed by instructional materials $(p=0.013)$. Results showed that there is enough evidence to reject the null hypothesis that there will be no significant relative influence of selected school climate indices on teacher's job performance in Oyo State.

Hypothesis Six: There will be no significant gender difference in teachers' job satisfaction and performance in Oyo state.

Table 12. Gender Difference.

\begin{tabular}{|c|c|c|c|c|c|c|c|}
\hline Variable & Gender & $\mathbf{N}$ & Mean & SD & Std. Mean Error & $\mathbf{t}$ & $\mathbf{P}$ \\
\hline \multirow{2}{*}{ Job Satisfaction } & Female & 911 & 59.129 & 5.589 & 0.1833 & \multirow{2}{*}{-3.133} & \multirow{2}{*}{0.002} \\
\hline & Male & 589 & 60.000 & 4.569 & 0.1914 & & \\
\hline \multirow{2}{*}{ Job Performance } & Female & 911 & 67.419 & 4.555 & 0.1494 & \multirow{2}{*}{-1.598} & \multirow{2}{*}{0.110} \\
\hline & Male & 589 & 67.789 & 4.005 & 0.1677 & & \\
\hline
\end{tabular}

Sig. $\mathrm{P}<0.05$

Table 12 above reported average score of female teachers' level job satisfaction and performance to be $59.129 ; 67.419$ respectively while that of male to be 60.000 and 67.789 respectively. Skewness statistics revealed that the distribution teachers' job satisfaction and performance scores for both gender are negatively skewed. Independent t-test statistics revealed that there was significant gender difference in teachers' job satisfaction $(\mathrm{t}=-3.133, \mathrm{P}<0.05)$ but no significant gender difference in teachers' job performance $(\mathrm{t}=-1.598, \mathrm{P}>0.05)$ in Oyo State.

\section{Discussion of Findings}

For research question one, the analysis conducted in this study revealed that the level of job satisfaction of public secondary school teachers in Oyo Sate is low with the overall weighted average of 2.3802 as against 2.50 . The discovery of this study agreed with the findings of some researchers which indicated that teachers are not satisfied with teaching profession because it does not enjoy due respect from the government, parents, students and the society at large [2, 4].

For research question two, the analysis conducted in this study revealed that the level of teacher job performance in public secondary school in Oyo State is high with overall weighted average of 2.7019 as against 2.50. This findings agreed with the findings in a study on factors of teacher job performance among secondary school teachers in Lagos State, Nigeria [8]. On the contrary, it was discovered that teacher job performance is low as a result of incessant close of schools due to strike actions [7].

For research question three, analysis of the study conducted revealed that the state of school climate in public secondary schools in Oyo State is far from being satisfactory. The result is in consonant with the findings of some researchers which showed that teachers often teach in a poor school environment with dilapidated buildings $[10,15]$.

For hypothesis one, the analysis conducted in this study revealed that school climate indices combined, exerted significant positive influence on job satisfaction and performance of teachers in public secondary schools in Oyo
State. Results do accord with the findings in a study which showed that school climate have proven to be the primary variable affecting teachers' job satisfaction [5].

For hypothesis two, the analysis conducted in this study revealed that school climate indices combined, exerted significant positive influence on job satisfaction of public secondary schools in Oyo State. This discovery agreed with the findings of some researchers which revealed that school climate significantly influenced teacher job satisfaction $[4,11]$.

For hypothesis three, the analysis conducted in this study revealed that school climate indices exerted significant relative influence on job satisfaction of teachers in public secondary schools in Oyo State. The discovery of this study aligned with the discoveries of some researchers which revealed that school environment positively influenced job satisfaction $[3,6]$.

For hypothesis four, the analysis conducted in this study revealed that school climate indices exerted combined significant positive influence on job performance of public secondary schools in Oyo State. This finding is in consonant with the findings of some researchers which indicated that school climates significantly influenced teacher job performance $[2,13]$.

For hypothesis five, the analysis conducted in this study revealed that school climate indices exerted significant relative influence on teacher job performance in public secondary school in Oyo State. This discovery aligned with the findings in a study on creating an enabling school environment for effective job performance among primary school teachers in Oyo State, Nigeria [16].

For hypothesis six, the analysis conducted in this study revealed that there was significant difference in job satisfaction of female and male teachers in Oyo State. The discovery of this study is in agreement with some researchers which revealed that gender notably influenced the level of job satisfaction of teachers $[17,18]$.

For hypothesis seven, the analysis conducted in this study revealed that there was no significant difference in job performance of female and male teachers in public secondary schools in Oyo State. This study agreed with the discovery in 
a study on exploring workers job performance and role of gender differences [19].

\section{Conclusion}

In conclusion, this paper categorically declared that school climate indices that is; usage of instructional materials to teach by the teachers, availability of modern library, well equipped laboratories for practical, and conducive classroom for leaning are directly proportion to teachers' job satisfaction and performance. Correct teacher-student ratio $(30: 1$ or $35: 1)$ will reduce stress on the part of the teacher as well as the learners. Also, increase in teachers' job satisfaction leads to increase in job performance. And increase in teachers' job performance will definitely influence the learners' academic performance positively. Hence, unconducive (non-functional) classroom environment, lack of laboratory equipment and modern libraries coupled with non-availability of instructional materials in Oyo state public secondary schools have both narrowed and watered down the teaching-learning activities to a bundle of burgled and uninteresting routine for both the learners and the teachers. Learners are discouraged as they only struggled and managed to scale through the secondary school system. Teachers are incapacitated and confined to discharge of duties in a seemingly uncultured, porous and unplanned environment. This account for low job satisfaction and performance of teachers is thereby falling short of societal expectations. Moreover, the study concluded that the gender difference in teachers' job satisfaction in public secondary schools in Oyo state does not extend to the job performance. This implies that gender has nothing to do with job performance. Thus, the individual performance is based on the job satisfaction.

\section{Recommendations}

Based on the findings of this study, the following recommendations were made:

i. Government both at the federal and state levels should allocate sufficient funds in the budget for the provision of instructional materials, modern libraries, well equipped laboratories and classrooms.

ii. Non-Governmental Organisations should assist in provision of educational facilities and instructional materials in schools.

iii. Teachers should imbibe and cultivate a practical teaching approach. Teachers should carefully plan the lessons and improvise instructional materials when necessary.

iv. Schools should develop a good maintenance culture. School principals should ensure that available educational facilities are properly put in a functional and useable state.

\section{References}

[1] Abiodun, M. G. and Gbadebo, O. A., "Job satisfaction status of primary school teachers in Ota, Nigeria", Eurpoean Journal of Educational Studies, Vol. 14 (12) 2012, Pp 201-220.
[2] Emu, W. H. \& Nwannunu, B. I. "Management of school climate and teachers job performance in secondary schools in Calabar education zone", Cross River state. Global Journal of Educational Research Vol. 17. 2018. Pp 127-137.

[3] Ammanuel, A. T. Human resource management for education practitioners in Africa. 2nd edition. Nairobi CUFA Press (2014) Pp 105-215.

[4] Oyebamiji, F. F., "Impact of job satisfaction dimensions on job performance in a small and medium enterprises in Ibadan, South Western Nigeria", Interdisciplinary Journal of Contemporary Research in Business, Vol. 4 (11) 2013, Pp 75-115.

[5] Tillman, W. R. and Tillman, C. J., "And you thought it was an apple: a study of job satisfaction among teachers", Academy of Educational Leadership Journal, Vol. 18 (2) 2014, Pp 7184. Vol. 35 (6) 2011, Pp 92-107.

[6] Yousaf, D. A., "Satisfaction with job security as a predator of organizational commitment and job performance in multicultural environment", International Journal of Manpower, Vol. 3 (1).s

[7] Fauzilah, S., Noryati, Y. and Zaharah, D., "The influence of skill levels on job performance of public service employees in Malaysia", Educational research. Available Online: http://www.semanticscholar.org Corpus ID: 187118802011

[8] Mosqsood, A. Ishtiaq. H., Sarfraz, A. and Quamarud, D., "A study of the factors affecting the professional performance of teachers at higher education level in Khyber Pakhtunkhwa", Academic Research International, Vol. 2 (2) 2012, Pp 73-89.

[9] Rasheed, N. S., "The effects of organization climate on managerial job performance and job satisfaction," Journal of Curriculum and Supervision, Vol. 1 (2) 2013, Pp 41-63.

[10] Obineli, S. A. Relationship among levels of mental dysfunction, occupational maladjustment and performance of civil servants in Anambra State. Unpublished thesis, Nnamdi Azikwe University, Awka, (2010) pp 38-69.

[11] Obinmal, F. K. Human resource management education perspectives. Educational development and bureau, 4 (6), (2018) 63-85.

[12] Klassen, R. M. \& Anderson, C. J. K. "How times change: Secondary teachers' job satisfaction and dissatisfaction in 1962 and 2007'. British Educational Research Journal Vol. 35 (5) 2013, Pp 134-145.

[13] Khannan, N. \& Johnson, C. "Passing as black: racial identity work among biracial American. Social Psychology Quarterly, Vol. 73 (4), 2010, Pp 380-397.

[14] Oredein, A. O. "Lecturer job commitment and job performance: leadership implications for Nigerian higher education development". Journal of Educational Review (JER). A Serial International Publication from New Delhi (India), 7 (1), January-March 2014, Pp 133-138.

[15] Lodess, S. \& Jowore, W. "Effect of school climate on teachers' job satisfaction in government schools of Hawassa city administration". The International Journal of Humanities \& Social Studies. Vol. 3 May, 2015, Pp 112-132.

[16] Ojo, P. D. Creating an enabling school environment for effective job performance among primary school teachers in Oyo State, Journal of social science and behavioral sciences, Vol. 18(2), (2016) pp 71-79. 
[17] Kim, S. Gender difference in job satisfaction of public employees, International journal of education and research, Vol, 52(9), (2015), pp 102-119.

[18] Johnson, R. B. Exploring workers job satisfaction and role of gender differences, Indian journal of social science researchers, Vol. 3(2). (2016) pp 21-32.
[19] Beckly, C. T. Job satisfaction and gender differences: an expanded specification, International journal of manpower, Vol. 12(1), (2017) pp 30-62. 